\title{
Domán László
}

\section{AZ AIRBUS H145M HELIKOPTER ÉS A TÚLÉLŐKÉPESSÉG}

DOI: $10.32560 / \mathrm{rk} .2019 .1 .8$

A cikkben a H145M típusú könnyü, többcélú helikoptert kivánom bemutatni. A fejlesztés, majd föbb harcászat-technikai jellemzök leirását követöen, a helikopter túlélöképesség szempontjából történö elemzésével foglalkozom. Részletezve a szerkezeti felépitést, a különbözö önvédelmi eszközöket, végezetül a jelenleg alkalmazott fedélzeti fegyvereket.

Kulcsszavak: túlélöképesség, helikopter, önvédelmi eszközök, fegyverzet

\section{BEVEZETÉS}

A Magyarország a Zrínyi 2026 Honvédelmi és Haderőfejlesztési Program keretében 2018-ban megrendelt a HForce fegyverrendszerrel ellátott $20 \mathrm{db}$ H145M helikoptert (1. ábra) az Airbus Helicopters vállalattól. A beszerzés célja többek között a szárazföldi csapatok támogatása érdekében a lassan üzemidejük és rendszerben tarthatóságuk végső határidejét elérő szovjet gyártású helikopterek kiválása miatt, a helikopterflotta megújítása [1].

A publikációban a szerző arra keresi a választ, hogy ennek a helikopter típusnak a túlélőképességet növelő technikai megoldásai, hogyan járulnak hozzá a Magyar Honvédség forgószárnyas képességének megújításához, mivel a helikopterek harctéri túlélésének biztosítása elsődleges fontosságú feladat a műveletek tervezésben és a végrehajtásában egyaránt.

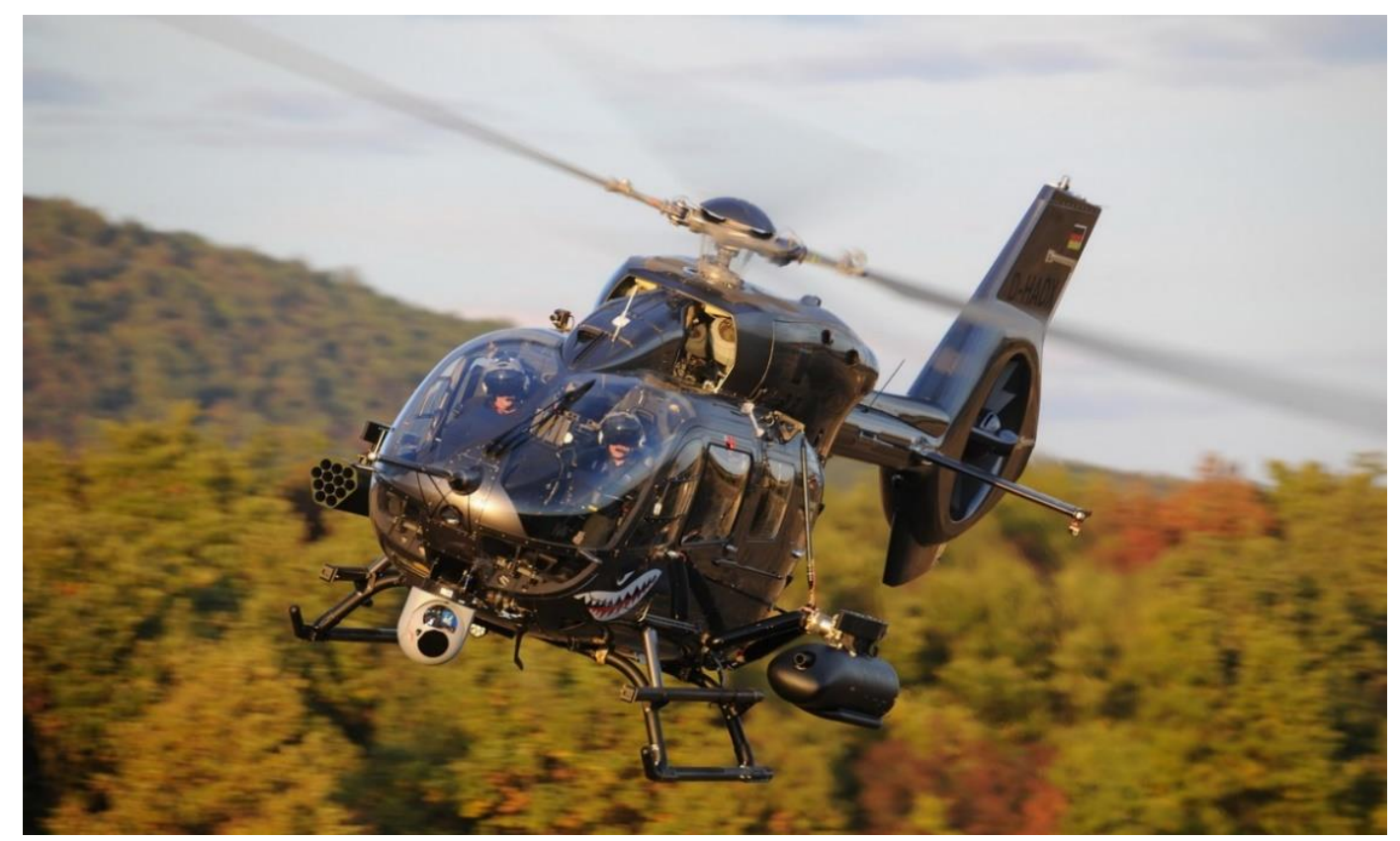

1. ábra Az Airbus H145M helikopter [2] 


\section{AZ AIRBUS H145M HELIKOPTER FEJLESZTÉSE ÉS VÁLTOZATAI}

\section{Előzmények}

A német $\mathrm{MBB}^{1}$ és a japán Kawasaki által kifejlesztett BK117 kéthajtóműves könnyű helikopter prototípusának első repülése 1979-ben volt, ezt követően a 2004-es sorozatgyártásáig több száz ilyen helikoptert gyártottak. A BK117 típust a mai napig is számos helyen használják rendvédelmi, kutató-mentő, egészségügyi és szállítási feladatokra egyaránt. A 1990 években, népszerüségének köszönhetően a típust tovább fejlesztették. Ennek során a gyártó EC135 helikopterének modern avionikai rendszereit és fülke kialakítását felhasználva kombinálták az előd BK117 C1 verziójának jól bevált hagyományos elrendezésű farok részével, így kialakítva az új típust, amely a BK117 C2 jelölés mellett 1997-ben megkapta a típus alkalmassági bizonyítványt. Ezt követően 1999-ben a kedvezőbb marketing célok érdekében a helikopter megkapta az EC145 típus jelzést [3].

Az EC145-nek számos előnye volt az elődjéhez képest, köztük a nagyobb hatótávolság és nagyobb hasznos teherbírás, illetve jelentősen megnövekedett kabin méret, a csökkent rezgés- és zajkibocsátás, valamint jelentősen egyszerüsödött a karbantartás és csökkentek az üzemeltetési költségek. Az EC145 zaj kibocsátása 60\%-kal alacsonyabb volt, mint például az BK 117 C1 helikopteré [4].

\section{További fejlesztések}

A következő években az Eurocopter elkezdte az EC145 továbbfejlesztését és 2011-ben EC145 T2 néven bemutatta az új típust. A tervezésnél jelentősen növekedett a helikopter teljesítménye, köszönhetően az új Arriel 2E hajtómüveknek és a modernizált forgószárny és faroklégcsavar kialakításnak. A helikopter avionikai rendszereinél számos fejlesztés történt, legjelentősebb ezek közül talán a 4 csatornás robotpilóta alkalmazása volt. 2014-ben az EC145 T2 típus megkapta az EASA ${ }^{2}$ és FAA ${ }^{3}$ típus alkalmassági bizonyítványát. Ezt követően 2015-től immár Airbus helikopterként, a H145 névén gyártják. Szintén ebben az évben mutatták be az EC145e típust, amely az EC145 T2 tömegében könnyített és olcsóbb verziója, amit néhány avionikai rendszer elhagyásával oldottak meg. Az EC145e esetében az EASA 2015 tavaszán adta ki a típus alkalmassági bizonyítványt [4].

\section{Katonai változat}

2006-ban az UH-145, az EC145 katonai verzióját választották ki az Egyesült Államok hadsereg könnyü támogató helikoptereként. Az Amerikai Védelmi Minisztérium az UH-72 Lakota néven rendszeresíttette a helikoptert. 2014-ben volt az EC645 T2, a EC145 katonai verziójának első teszt repülése. Az EC645 T2-t a katonai feladatok ellátása érdekében fegyver függesztési pontokkal, elektronikai ellentevékenység rendszerrel, elektronikai támogató rendszerrel, a teher emelés és rögzítés céljából ereszkedőkötéllel, teherkampóval és csörlőkkel szerelték fel. 2015ben Airbus H145M néven kapta meg az EASA típus alkalmassági bizonyítványát [5].

\footnotetext{
${ }^{1}$ MBB - Messerschmitt-Bölkow-Blohm

${ }^{2}$ EASA: European Aviation Safety Agency, Európai Repülésbiztonsági Ügynökség

${ }^{3}$ FAA: Federal Aviation Administration, Szövetségi Légügyi Hivatal
} 


\section{AZ AIRBUS H145M FÖBB HARCÁSZATI-TECHNIKAI JELLEMZÖI}

\section{Sárkány-hajtómü}

A H145M nagyobb belső térrel rendelkezik, mint az első BK 117 C1, a helikopterben a pilótákon kívül, speciális üléskialakításnak köszönhetően 10 fö katona elhelyezése lehetséges. A $46 \mathrm{~cm}$ hosszúság és $13 \mathrm{~cm}$ szélesség növekedés következtében az új típus belső kabin mérete jelentősen megnőtt az elődhöz képest.

A BK 117-hez képest további javítások közé tartozik a még nagyobb megengedett felszállótömeg, amely így 3,7 tonnára nőtt és a nagyobb 690 km-es hatótávolság, amelyet részben a EC135 típustól átvett kompozit forgószárnylapátoknak és az összesen $730 \mathrm{~kg}$ kerozin tárolására alkalmas $2 \mathrm{db}$ üzemanyag tartálynak köszönhet, amelyeket a helikopter padlózat alatt helyeztek el [6]. A helikopter $2 \mathrm{db}$ Safran Arriel 2E típusú hajtómüvel rendelkezik (2. ábra), amellyel stabilizált üzemmódon egyenként, $575 \mathrm{~kW}$ teljesítményt adnak le, ami a felszállás idejére $667 \mathrm{~kW}$-ra növelhető. A diagnosztikai funkciókkal ellátott, kétcsatornás teljeskörü digitális hajtómű szabályozásnak (FADEC) ${ }^{4}$ és továbbfejlesztett átviteli rendszernek köszönhetően, vészhelyzetben, az egyik erőforrás leállása, hibája esetén az üzemelő hajtómű teljesítménye fél percig maximálisan 800 kW-ra, két percig $775 \mathrm{~kW}$ pedig növelhető, amely nagyban növeli a helikopter túlélőképességét. A gyártás kezdetén 4000 órás javításközi üzemidőt terveztek, amit a tapasztalatok alapján 6000 órára kívánnak növelni, ez harmonizál a sárkányszerkezet javításközi üzemidejével [7].

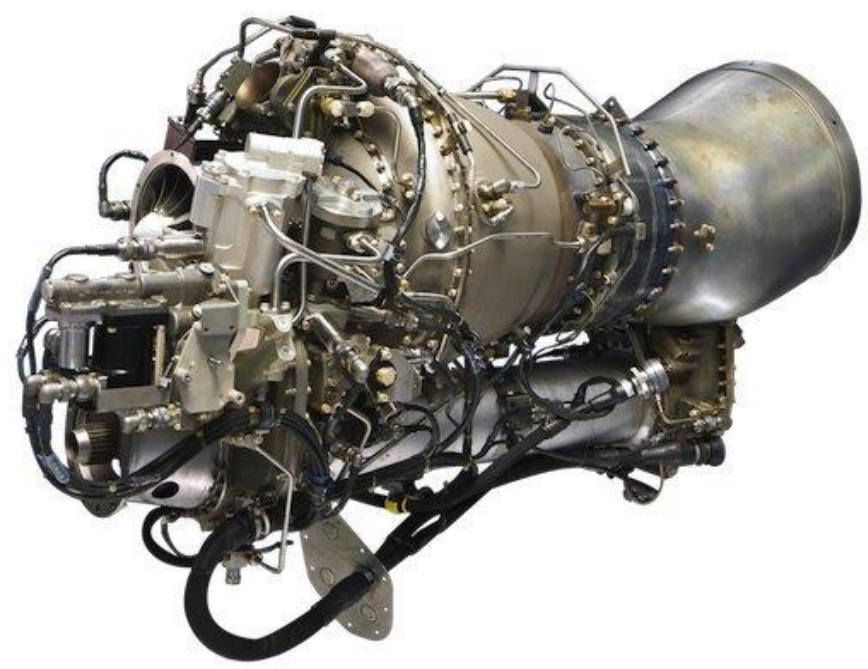

2. ábra Safran Arriel 2E típusú hajtómü [8]

A H145M-nél a teljesen fix bekötésű csukló nélküli forgószárnyat és monolit (egy tömbből készült) titán forgószárnyagyat alkalmaznak a jobb repülési tulajdonságok elérése érdekében (3. ábra). Ennek a megoldásnak az egyszerü felépítés, könnyű karbantarthatóság, a kis légellenállás és hosszú élettartam a jellemzője. Az alkalmazott elasztomerek hosszú üzemideje annak köszönhető, hogy a dinamikus fárasztás (esetünkben vibráció) esetén, a fémekhez hasonlóan (Wöhler-diagram szerinti) terhelhetőség-csökkenés nem tapasztalható, nincs kimutatható kifáradási határuk. Az így kialakított forgószárnyagyak esetében nem változik meg a lapátok

\footnotetext{
${ }^{4}$ FADEC: Full-Authority Digital Engine Controls, teljeskörü digitális hajtómű szabályozás
} 
vezérlésének elve, csak a hagyományos csuklók szerepét különféle, előre meghatározott rugalmasságú, illetve csillapítási tulajdonságú anyagok veszik át [9].

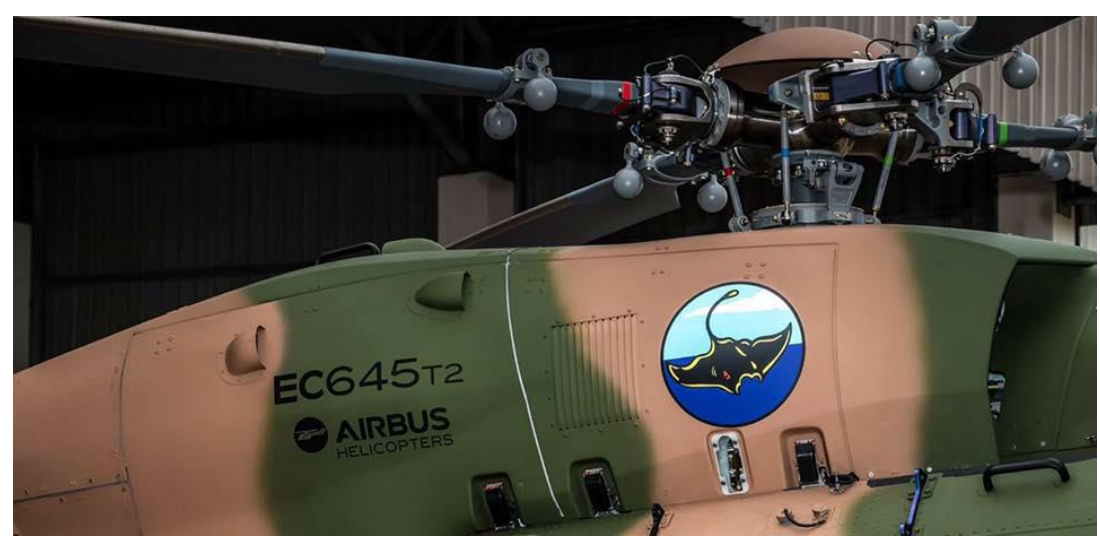

3. ábra Forgószárny bekötés [8]

\section{Avionika}

Az avionika rendszer a következő elemeket foglalja magában:

$\rightarrow$ korszerü katonai IFR/VFR ${ }^{5}$ navigációt biztosító eszközök;

$\rightarrow$ zavarvédett, titkosított, müholdas kommunikációra alkalmas $\mathrm{VHF} / \mathrm{UHF}^{6}$ rádióállomások;

$\rightarrow$ négytengelyes robotpilóta;

$\downarrow$ idegen-barát felismerő berendezés (IFF) ${ }^{7}$, a NATO országok által rendszeresített helikopterek Mark XIIA idegen-barát felismerő berendezésének Mode 5 titkosított (kriptografikus) üzemmóddal is rendelkeznie kell, mivel ennek üzemmódnak a használata 2020 nyarától kötelező lesz minden NATO által vezetett koalíciós müvelet esetében [10];

$\uparrow$ vészjeladó $(\mathrm{ELT})^{8}$;

† a földközelség jelző (HTAWS) ${ }^{9}$ jelzi és figyelmezteti a személyzetet a számára veszélyes szárazföldi akadályokról az aktuális repülési útvonal során;

$\downarrow$ éjjellátó- (NVG) ${ }^{10}$ kompatibilis fülke müszerezettség, lehetővé téve az éjszakai alkalmazást is;

$\downarrow$ Thales MEGHAS avionikai rendszer.

A helikopter képes teljes mértékben GPS navigáció segítségével repülni a felszállástól a leszállásig, követve az előre beprogramozott útvonalat, még kedvezőtlen meteorológiai körülmények esetén is [11].

A H145M helikopter teljesen digitalizált müszerfallal rendelkezik, többek között az aktív mátrix LCD $^{11}$ kijelzőkkel ellátott Thales MEGHAS avionikai rendszerét is tartalmazza (4. ábra), amely számtalan funkciót képes egyidejűleg integráltan kezelni, többek között a robotpilótától, a repülésvezérlésen keresztül, a navigációs és a hajtómü vezérlő rendszereit is. Emellett folya-

\footnotetext{
${ }^{5}$ IFR/VFR: Instrument Flight Rules/Visual Flight Rules, müszer repülési szabályok/ látva repülési szabályok

${ }^{6} \mathrm{VHF} / \mathrm{UHF}$ - Very High Frequency/Ultra High Frequency

${ }^{7}$ IFF - Identification, Friend or Foe, idegen-barát felismerő berendezés

${ }^{8}$ ELT - Emergency Locator Transmitter, vészjeladó

${ }^{9}$ HTAWS - Helicopter Terrain Awareness System, helikopter földközelség jelző rendszer

${ }^{10} \mathrm{NVG}$ - Night Vision Goggle, éjjellátó szemüveg

${ }^{11}$ LCD - Liquid Crystal Display, folyadékkristályos kijelző
} 
matosan figyeli a helikopter összes alrendszerének az állapotát és az üzemeltetés során az esetleges hibaelhárítás gyorsan elvégezhető és így a karbantartási tevékenységek teljes mértékben optimalizálhatók [12] [13].

Az egyetlen képernyőn megjelenített összes repülési paraméter célja, hogy segítse a pilótát a helyzet gyors elemzésében és értékelésében annak érdekében, hogy továbbra is teljes mértékben csak az adott feladat végrehajtására koncentráljon.

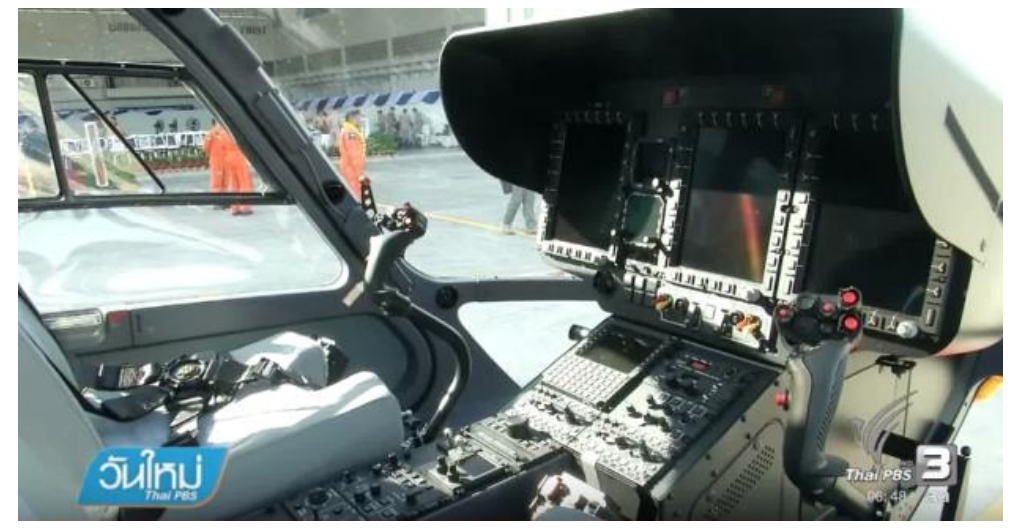

4. ábra Müszerfal [8]

\section{H145M technikai paraméterei}

$\dashv$ személyzet: 1 helikoptervezető vagy 1 helikoptervezető és 1 helikoptervezető-operátor;

$\rightarrow$ a tehertér befogadóképessége: max. 10 fö;

$\downarrow$ hossz: 11,69 m;

$\uparrow$ forgószárny átmérő: $11,0 \mathrm{~m}$;

$\rightarrow$ magasság: 3,95 m;

† üres tömeg: $1919 \mathrm{~kg}$;

$\uparrow$ hasznos teher: $1696 \mathrm{~kg}$;

$\rightarrow$ max. felszálló tömeg: $3800 \mathrm{~kg}$;

$\rightarrow$ hajtómü: $2 \mathrm{db}$ Safran Arriel 2E, egyenként $575 \mathrm{~kW}$;

$\uparrow$ maximum sebesség: $269 \mathrm{~km} / \mathrm{h}$;

$\rightarrow$ utazó sebesség: $240 \mathrm{~km} / \mathrm{h}$;

$\rightarrow$ hatótáv: $685 \mathrm{~km}$;

$\rightarrow$ gyakorlati csúcsmagasság: 4018 m;

$\rightarrow$ emelkedési sebesség: $8,13 \mathrm{~m} / \mathrm{s}$ [7].

\section{A TÚLÉLŐKÉPESSÉGET NÖVELŐ MEGOLDÁSOK}

A harci helikopterek hatékonysági mutatója

$$
W=P_{m} \cdot P_{t} \cdot P_{m b}
$$

ahol

† $P_{m}$ - csapásmérő képesség (az ellenséges cél megsemmisítési valószínűsége);

$\neg P_{t}$-túlélőképesség (eredményes önvédelem képessége);

$\downarrow \quad P_{m b}-$ müszaki megbízhatóság (hibamentes müködés valószínüsége) [14]. 
Az Amerikai Egyesült Államok Védelmi Minisztériuma is a repülőeszközök túlélőképességének biztosítását az egyik legfontosabb tervezési szempontnak tekinti. A túlélőképességét a repülőeszközök teljes életciklusa alatt biztosítani kell, a rendszerbeállítástól a kivonásig. A legújabb 4. és 5. generációs repülőgépek esetében a túlélőképességet növelő elemek már a tervezés korai szakaszában megjelennek [15].

Robert E. Ball ${ }^{12}$ szerint „a légijármü harci túlélőképessége egy légijármü azon tulajdonsága, hogy képes elkerülni vagy kivédeni az ember által létrehozott ellenséges környezet hatásait" [16].

A cikkben a H145M típusú helikopter túlélőképességét kizárólag a müszaki megoldások közül is, a szerkezeti felépítés és az önvédelmi eszközök alkalmazása alapján kívánom bemutatni.

Szerkezeti túlélőképességnek nevezzük azt, amikor a helikopter szerkezeti kialakítása és megerősítése védelmet nyújt a különböző pusztítóeszközök ellen, lehetővé téve a különböző túlterhelések elviselését, vagy egyszerüen megóvja a gépszemélyzetet és az utasokat a különböző környezeti hatásoktól. Ide sorolhatjuk a megfelelő manőverezőképességet, a páncélvédelmet és a megerősített sárkány teherviselő rendszert, a fedélzeti elektronikánál és a sárkány-hajtómü rendszereknél a redundáns felépítést, a megerősített futóművet, az alacsony zajszíntű hajtómüveket, forgószárny és faroklégcsavar-lapátokat, a tüzoltó és robbanást megelőző rendszereket, a radar keresztmetszet csökkentést, infravörös kisugárzás csökkentését az egyéb álcázó képesség kialakítását, vagy akár a valamilyen szintű lopakodó képesség kialakítását.

Az önvédelmi berendezések a fedélzeten található azon eszközök, melyek érzékelik és azonosítják a légijárművet ért különböző EMH ${ }^{13}$ besugárzásokat, majd zavarják és megtévesztik azok forrását, ezáltal eltérítik a repülőeszköz irányába indított rakétákat [17] [18].

\section{Szerkezeti túlélöképesség}

\section{Sérülés, megsemmisülés elleni védelem}

A H145M esetében a sérülés, megsemmisülés ellen védelem érdekében preventív jelleggel a sárkányszerkezet páncélvédettségét megnövelték, hogy a hagyományos kézi tűzfegyverek elleni védelmét biztosítson, nem csak a légijármünek, de a személyzetnek is.

A tüzelőanyag rendszernek a robbanástól vagy a tủztől védelme érdekében az öntömítő anyaggal bevont üzemanyag tartályokat alkalmaznak, amelyek akár a $20 \mathrm{~mm}$-es lövedékek és repeszek ellen is védelmet nyújthat, növelve ezzel a helikopter túlélőképességet a harctéren. Az ilyen típusú üzemanyag tartályok, köszönhetően a speciális technológiának rövid idő alatt megállítják az üzemanyag szivárgását, mely biztosítja a feladat további végrehajtását vagy a bázisra történő visszatérést [19].

Egyes repülőgépgyártók szerint a legelterjedtebb és bizonyítottan leghatékonyabb védelmi megoldás, ha a tüzelőanyag rendszer csővezetékeit nem hagyják szabadon, hanem ún. üzemanyag cellákban vezetik a megfelelő helyekre. További biztonsági megoldás a törzstartályokhoz kapcsolódó habképző alrendszer, mely tüzelfojtó üregkitöltő habot juttat a tartályok szabad tereibe szükség esetén. Más repülőgépgyárak elegendőnek tartják a tüzelőanyag tartályok semleges gázzal való feltöltését tűzveszély estében (5. ábra).

\footnotetext{
${ }^{12}$ Pofesszor Robert E. Ball, a légijárművek túlélőképesség vizsgálatának amerikai szakértője

${ }^{13}$ EMH: elektromágneses hullám
} 
A megbízhatóságot növelö elemek között szerepel a létfontosságú rendszereknél a redundanciás struktúra alkalmazása. A 2 db hajtómü, illetve a hajtómű vezérlésnél, a helikopter repülésvezérlő rendszernél alkalmazott tartalék rendszerek nagyban hozzájárulnak a sebezhetőség csökkentéséhez. A három, esetlenként négyszeres közvetlen elektromos kapcsolat mellé tartalékként mechanikus rendszereket is kiépítenek biztosítva a megfelelő megbízhatóságot [15].

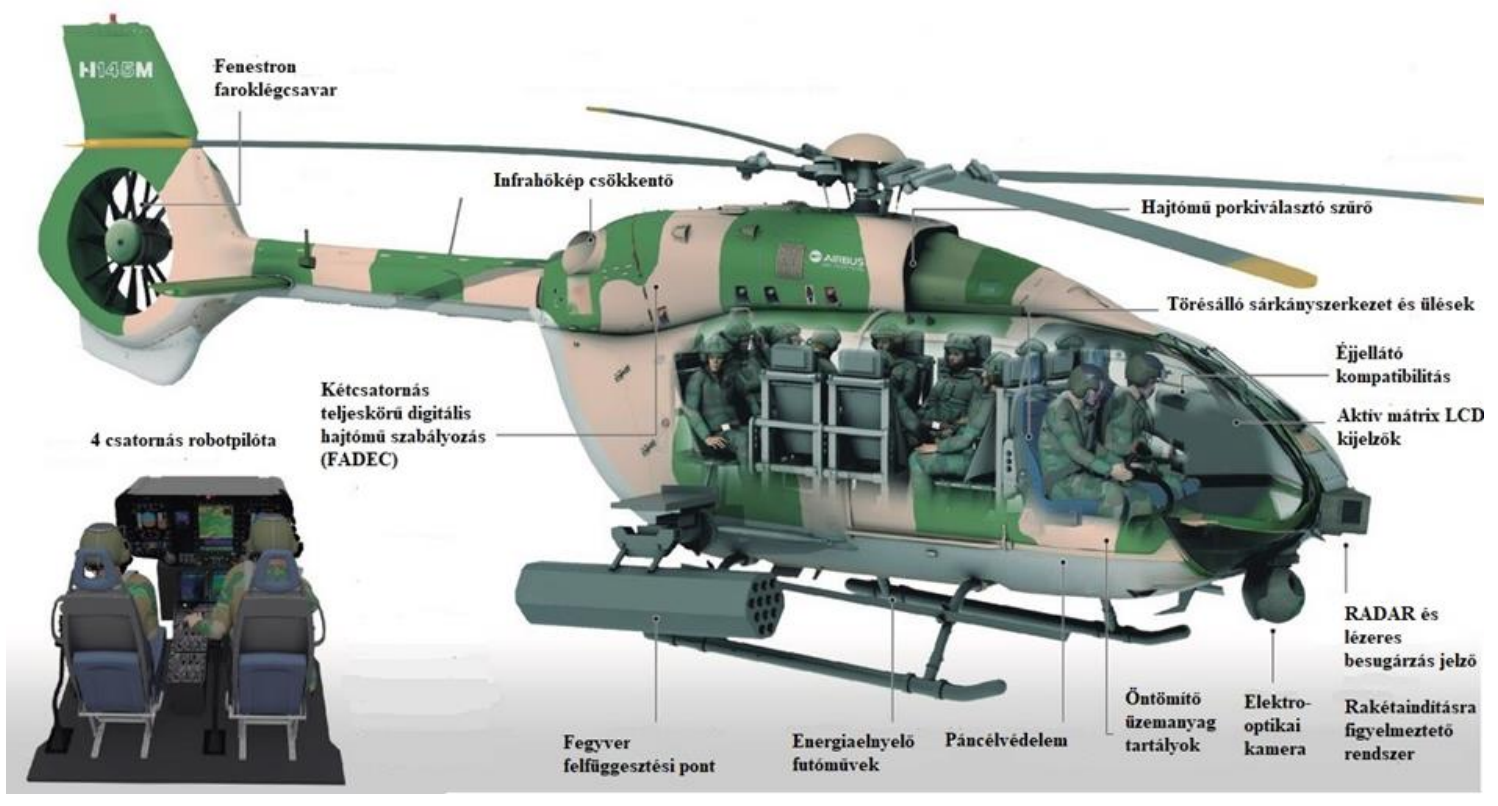

5.ábra Túlélőképességet növelö megoldások [20]

\section{A helikopter-személyzet védelme}

A földközeli magasságból lezuhant helikopterek esetében megnyugtató védelmet az jelenhet, ha a helikopter törzsét konstrukciósan alkalmassá teszik a benne ülők sérülésmentes túlélésének biztosítására, vagyis a lezuhanásból származó ütközési energia elnyelését a leghosszabb fékezési úthosszon kell biztosítani. Ez csak a sárkány meghatározott elemeinek egymást követő, irányított deformációjával lehetséges. A H145M esetében egy energiaelnyelő csúszótalpas megoldást választottak, ami egyszerü, könnyủ és megbízható, de növeli a helikopter légellenállását. Hátránya ennek a megoldásnak, hogy a földi mozgatásához speciális kiegészítő eszközökre van szükség. A helikopterek tervezésénél, olyan megoldásokat alkalmaztak, melyek biztosíthatják a törésállóságot a sárkányszerkezet és az ülések szempontjából is. A vietnámi háború tapasztalati, ahol számos személyzet szenvedett gerinc sérülést, egy egyébként túlélt balesetben, adták meg a fő lökést a kutatásoknak és kezdtek el olyan energia elnyelő üléseket kifejleszteni, amelyek megvédhetik a személyzetet. A MIL STD 1290A ${ }^{14}$ szabvány határozza meg a törésállóság követelményeit a könnyü merevszárnyú és a helikopterek számára [21].

A megfelelő biztonságot adó ülések kialakításakor fontos követelmény, hogy a hosszirányú ütközések esetén, az ülésnek tilos kitörnie a padlózatból, illetve, hogy a függőleges irányú becsapódás esetén az ülésnek az energia elnyelés során, biztosítania kell, hogy a személyzet és a szállítandó személyek gerinc sérülésének a valószínűsége minimális legyen [22] (6. ábra).

\footnotetext{
${ }^{14}$ MIL STD 1290A - United States Military Standard Light Fixed And Rotary-Wing Aircraft Crash Resistance
} 


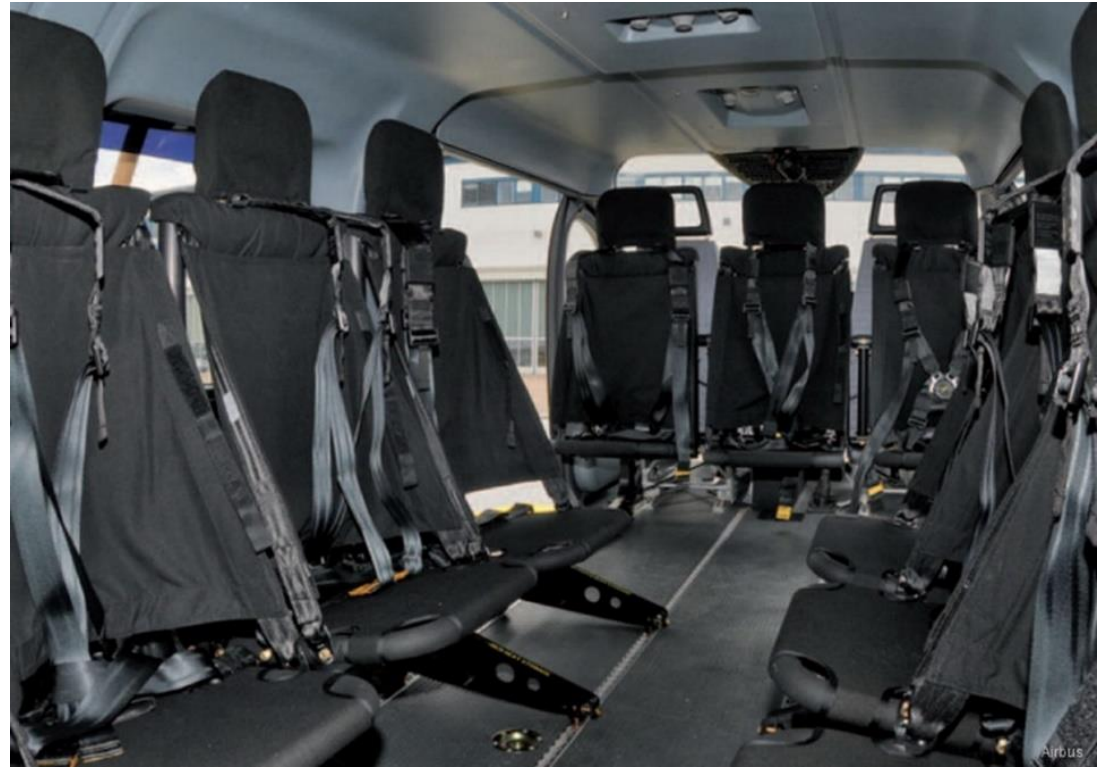

6. ábra Speciális üléskialakítás [23]

\section{A helikopter vizuális és akusztikai felderithetőségének csökkentése}

A H145M viszonylag kis méretének és speciális festésének köszönhetően nehezebben észrevehető, összehasonlítva a nagyobb méretű pl.: Mi-24, AH-64, Tiger, A129 stb. típusú helikopterekhez képest.

A helikopterek akusztikai felderíthetöségének csökkentése is fontos, de csak másodlagos cél, mivel hangjelek alapján irányítható automatikus fegyverek egyelőre nem léteznek. Természetesen az alacsonyabb zajszint, a kézi fegyverekkel szemben javítja a túlélés esélyeit [18]. A H145M a zaj és a vibráció szint további csökkentése érdekben „Fenestron” kialakítású faroklégcsavarral van felszerelve, amely kompozit anyagból készült aszimmetrikus lapátokat tartalmaz [24].

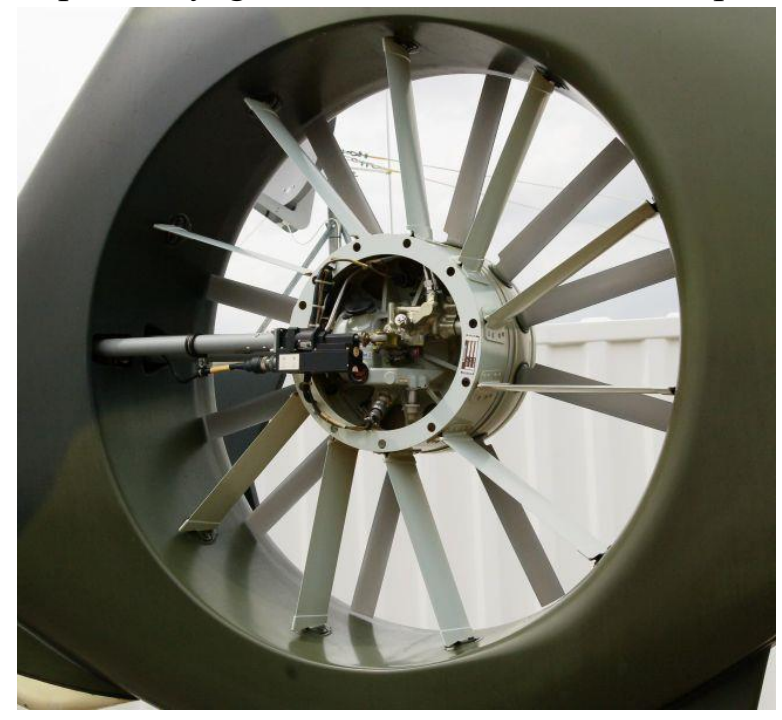

7. ábra Fenestron faroklégcsavar [26]

A „Fenestron”-nak, lásd 7. ábra egy nagy átméröjü cső belsejében forgó lapátokkal felszerelt dob egészét nevezik, amely a forgószárny reakció nyomatékát egyenlíti ki. A kialakításából adódik a jó hatásfok és az alacsony zajkibocsátási szint. A forgószárny és a faroklégcsavar által 
megmozgatott levegő nyomásának kiegyenlítődése hagyományos elrendezésben hirtelen, robbanásszerüen megy végbe, innen adódik a hagyományos kialakítású helikopterek jellegzetes hangja. A Fenestron alkalmazásával ez a kiegyenlítődés eltérő, a találkozó nyomáshullám-csúcsok sokkal kisebbek, illetve eltolt fázisban futnak össze. Kevésbé sérülékeny és balesetveszélyes az a hagyományos farok légcsavarokhoz képest is, így különösen előnyös többek között a csapatszállító helikoptereken való alkalmazása [25].

Emellett a forgószárny fordulatszám és nyomaték szinkronizátornak (VARTOMS) ${ }^{15}$ is köszönhetően a helikopter a legcsendesebb a kategóriájában, a kibocsátott zaja 6,5 dB alacsonyabb, mint az $\mathrm{ICAO}^{16}$ által ajánlott zajkibocsátási határérték [27].

\section{Önvédelmi eszközök}

A H145M rendelkezik elektronikai harc rendszerrel, amely tartalmaz radar és lézer besugárzás, valamint az infravörös tartományban müködő rakéta közeledés jelző berendezéseket. A rendszer része a passzív radar zavaró (dipól) és infracsapda kivető rendszer. A helikopterek önvédelmi berendezéseinek összessége egy integrált rendszert alkotva az elektronikai hadviselés részeként fogható fel, mely három fö területet ölel fel:

† Elektronikai védelmet, amely az elektronikai harc azon része, amely az ellenséges elektronikai harceszközökkel - melyek gyengíthetik, semlegesíthetik, vagy megsemmisíthetik a saját eröket - szembeni védelmére irányuló tevékenységeket foglalja magába. A helikoptereken az elektronikai védelemhez tartoznak, az infravörös höképet csökkentő eszközök, a lopakodó kialakítás, valamint a radarhullámokat elnyelő festés;

$\dashv$ Elektronikai támogatást, ami a harcfeladat során, a manőverek közben, az ellenséges eszközök által kisugárzott elektromágneses energia felderítésére és azonosítására szolgáló eszközök és eljárások összessége. A helikoptereken az elektronikai támogatás eszközeihez soroljuk a különböző radar és lézerbesugárzás-jelzőket, valamint az rakéta támadásra figyelmeztető rendszert;

$\downarrow$ Elektronikai ellentevékenységet, amelyekkel megakadályozható vagy csökkenthető az ellenség elektromágneses spektrumának hatásos használata zavarás, megsemmisítés vagy elektromágneses megtévesztés során. A helikopterek önvédelmi berendezési közül a radar- és infravörös önirányítású rakéták elleni csapdák, a radar és infravörös zavarók minősülnek az elektronikai ellentevékenység eszközeinek [17].

\section{Elektronikai védelem}

\section{A helikopter termikus kisugárzásának csökkentése}

A H145M helikopter hajtómü infravörös sugárzását csökkentették, növelve a helikopter passzív infravörös rakéta elleni védelmét. A repülő eszközök hajtóműveinél alkalmazott hőmérsékletcsökkentő eljárások elsődleges célja az, hogy a magas hőmérsékleten ionizálódó gáz mennyiségét csökkentsék. A hajtómüvek hőkibocsátását csökkentő módszereknek technikáknak (pl: a hajtómű hőt kibocsátó részei „optikai” láthatóságának csökkentése, kiáramló gázok hőmérsék-

\footnotetext{
${ }^{15}$ VARTOMS - Variable Rotorspeed And Torque Matching System, forgószárny fordulatszám és nyomaték szinkronizátor

${ }^{16}$ ICAO - International Civil Aviation Organization, Nemzetközi Polgári Repülési Szervezet
} 
letének csökkentése, sárkányszerkezet hömérsékletének a külső hőmérséklethez történő beállítása és a sárkányszerkezet visszaverő felületeinek csökkentése) köszönhetően a korszerü repülőgépek alig bocsátanak ki a környezetüknél melegebb gázokat. A módszerek célja az, hogy az infravörös sugárzás általános szintjét az alkalmazott infravörös célkoordinátorral rendelkező rakéták érzékenysége alá vigye, egyben a felderíthetőséget a háttérsugárzáshoz viszonyított kontraszt elmosásával a minimumra csökkentse [28].

\section{Elektronikai támogatás}

\section{Radar besugárzás jelző ${ }^{17}$ (RWR)}

Az RWR-t a légijárművet ért fenyegetések azonosítására és osztályozására lehet alkalmazni. A helikopter ELT/160(V)1 típusú RWR rendszere több széles sávú antennából áll, amelyek úgy vannak elhelyezve, hogy bármelyik irányból érzékeljék a besugárzás tényét. A berendezés folyamatosan vizsgálja a vett jelek különböző paramétereit, mint például a frekvenciát $(2-40 \mathrm{GHz}$ között, E sávtól a K sávig), a jel alakot, a besugárzás irányát, az impulzus ismétlési frekvenciáját. Az így nyer adatok segítségével a rendszer automatikusan elemzi, osztályozza, eltárolja és kijelzi akár a számára ismeretlen veszély forrásokat is, amelyekről az előre beprogramozott adatbázisa semmilyen információt nem tartalmazott.

A fejlett eszközök képesek együttműködni a repülőgép vezérlő rendszerrel, a kitérő manőverek végrehajtása érdekében, illetve a dipól és infracsapda kivetővel, hogy automatikusan kivetésre kerüljenek a zavaró csapdák [29].

\section{Lézer besugárzás jelző (LWR) ${ }^{18}$}

A lézer technológia fejlődésével párhuzamosan megjelentek a lézer irányítású rakéták, amelyek, a lokátor irányításúhoz képest sokkal pontosabb célzást és zavarvédelmet tesznek lehetővé.

Az ALTAS 2Q(B) típusú lézer besugárzás jelző (8. ábra) egy olyan típusú figyelmeztető rendszer, amely a kisugárzott lézert észleli, elemzi és meghatározza a sugárforrás irányát Érzékelt hullámhossz: $\lambda=0,5 \mu \mathrm{m}-1,65 \mu \mathrm{m}\left(\mathrm{LRF}^{19}\right.$ és $\left.\operatorname{LTD}^{20}\right), \lambda=0,8 \mu \mathrm{m}-1,1 \mu \mathrm{m}\left(\mathrm{LBR}^{21}\right)$, impulzus ismétlődési frekvencia: $1 \mathrm{kHz}-\mathrm{ig}$, felderítési valószínüség nagyobb, mint 95\% [30]. Mivel a kissugárzott lézerek nagyon keskeny nyalábúak és kevesebb energia szükséges a müködtetésükhöz, mint a félaktív lokátoros kialakításnál, ez megnehezíti a lézer irányítású eszközök észlelését [31].

Az LWR az azonosítást követően, figyelmezteti a légijármű személyzetét a veszélyforrásról, aki így megkezdheti a szükséges ellentevékenység végrehajtását, például kitérő manőverek végrehajtásával, lézeres zavaró vagy lézer ellentevékenység rendszer müködtetésével [32].

\footnotetext{
${ }^{17}$ RWR - Radar Warning Receiver, Radar besugárzás jelző

${ }^{18}$ LWR - Laser Warning Receiver, lézeres besugárzás jelző

${ }^{19}$ LRF- Laser Range Finder, lézeres távolságmérő

${ }^{20}$ LTD - Laser Target Designator, lézeres célmegjelölő

${ }^{21}$ LBR - Laser Beam Rider, lézeres célrávezetés
} 


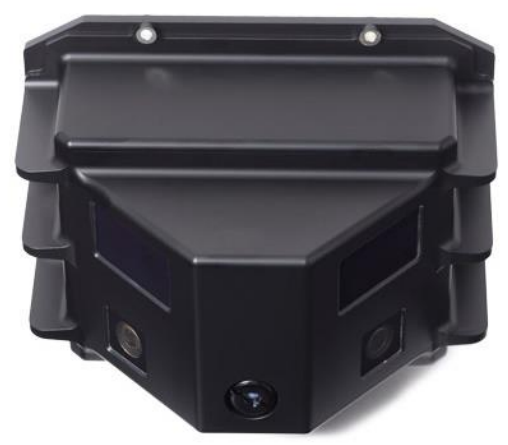

8. ábra ALTAS 2Q(B) LWR [30]

\section{Rakétaindításra figyelmeztető rendszer (MAWS)22}

A modern rakétaindításra figyelmeztető eszközök az impulzus-doppler RADAR (PDR) ${ }^{23}$ technológia, illetve az infravörös (IR) ${ }^{24}$ és/vagy az ultraibolya (UV) $)^{25}$ tartományú elektromágneses sugárzás érzékelését felhasználó opto-elektronikai rendszerek alapján működnek. A korszerü berendezések az emissziós adatokat is felhasználhatják az ellenséges rakéták típusának meghatározására, hogy lehetővé tegyék a célzott és megfelelő ellenintézkedéseket. A H145M típusú helikopteren alkalmazásra kerülő ultraibolya tartományban müködő AN/AAR-60 típusú berendezés [33] előnye (9. ábra), hogy sokkal alacsonyabb számú a téves riasztásokból adódó probléma az IR alapú rendszerekhez képest, emellett egyszerübb müszaki kivitelü, bármilyen időjárási körülmény között alkalmazható, illetve nincs szűksége külön hütésre és központi jelfeldolgozó rendszerre, mert az egyes szenzorok jelei külön-külön kerülnek feldolgozásra. Hátránya, hogy nagyobb magasságban kisebb a felderítési hatósugara, nem biztosít aktuális távolsági adatokat és csak a müködő hajtómüvel közeledő rakétákat érzékeli, amelyek hőt bocsátanak ki. Amint érzékeli a közeledő rakétát, a rendszer figyelmeztető jelet ad a személyzet részére és vizuálisan is kijelzi a rakéta, repülő eszközökhöz viszonyított helyzetét, majd automatikusan megkezdi a dipól és az infracsapdák kilövését [34].

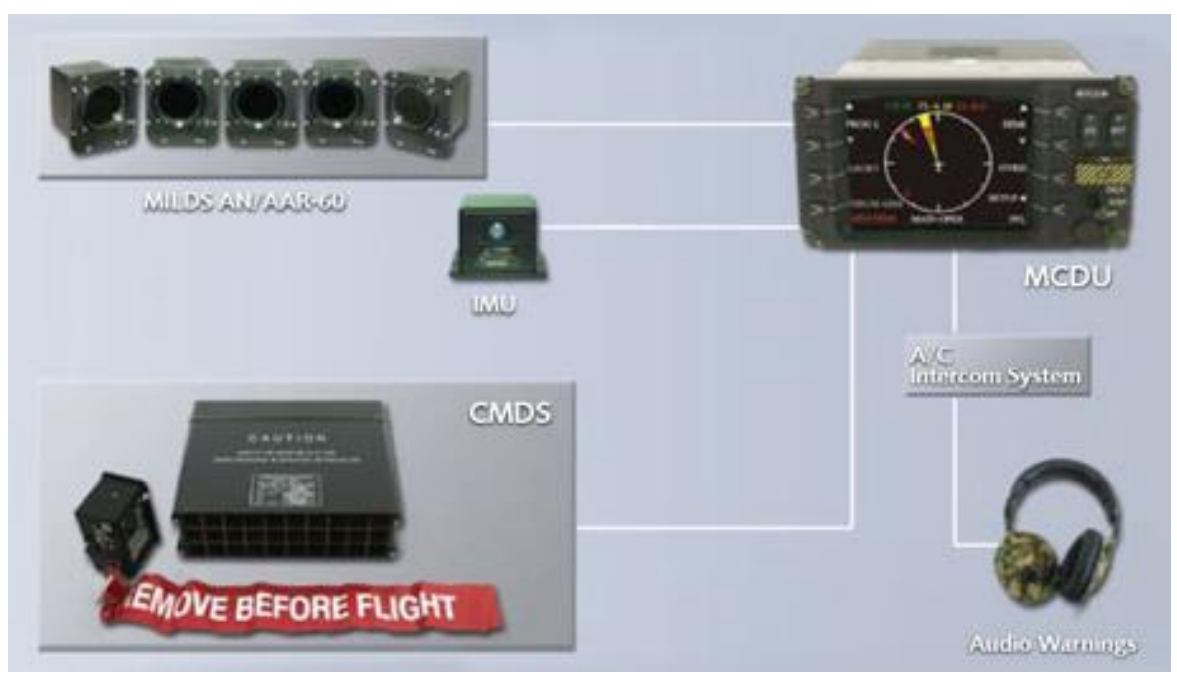

9. ábra AN/AAR-60 rakétaindításra figyelmeztető rendszer [35]

\footnotetext{
${ }^{22}$ MAWS - Missile Approach Warning System, rakétaindításra figyelmeztető rendszer

${ }^{23}$ PDR - Pulse-Doppler Radar, impulzus-doppler RADAR

${ }^{24}$ IR - InfraRed, infravörös tartományú elektromágneses sugárzás

${ }^{25}$ UV - Ultra Viola, ultraibolya tartományú elektromágneses sugárzás
} 


\section{Elektronikai ellentevékenység}

\section{Infracsapda (passzív infravörös zavaró)}

A H145M rendelkezik korszerű infracsapda kivetővel (10. ábra). Az új anyagokat tartalmazó infracsapdák tulajdonképpen lassan égnek, így biztosítva a kellően alacsony hőmérsékletet és a hosszú idejü égést. A viszonylagosan alacsony égési hőmérséklet miatt a hordozó repülőeszköz rejtve maradhat földi vizuális felderítés elől, ezáltal biztosítva légvédelmi fegyverek elleni védelmet, valamint a minél jobb spektrális hasonlóságot [36].

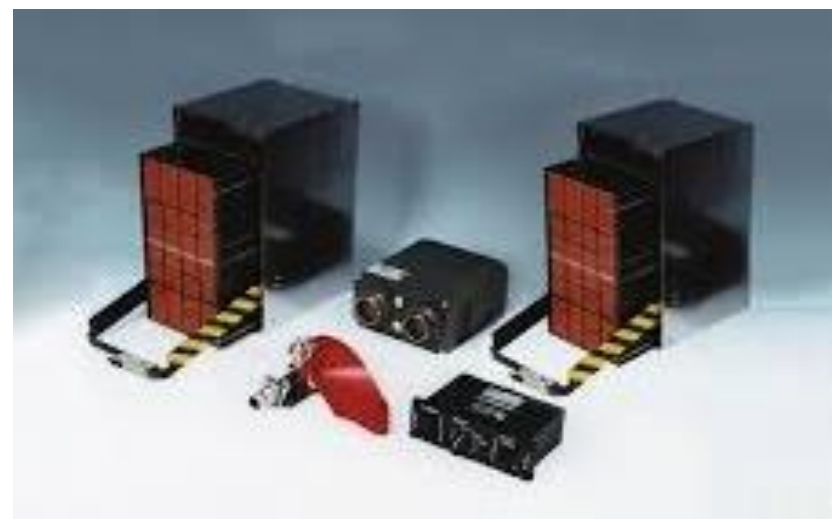

10. ábra Saphir-M infracsapda és dipól kivető [37]

\section{Passzív rádiólokátor zavaró (dipól kivető)}

A dipólok általában alumínium vagy egyéb fémmel bevont üvegszálból vagy mủanyagból készülnek (11. ábra). Ezek kivetése mintegy függönyként álcázza a légijármüvet és ezáltal hamis célokat generál a fenyegetést jelentő rádiólokációs eszközök számára.

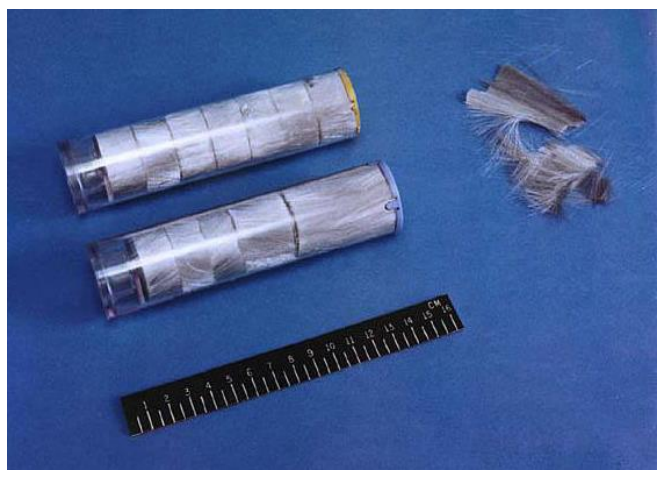

11. ábra RR-144 és RR-129 dipól [38]

\section{FEGYVER RENDSZER}

Az Eurocopter Tiger (EC665) harci helikopteren szerzett tapasztalatokat felhasználva az Airbus olyan fegyverzet vezérlő rendszert (HForce) fejlesztett ki, ami az adott feladat végrehajtásának céljából biztosítja a különböző fegyverrendszerek alkalmazhatóságát.

\section{HForce rendszer}

A HForce egy moduláris rendszernek tekinthető, különböző típusú helikopterek között is cserélhető többfunkciós fedélzeti számítógépet és számos fegyvertrendszert tartalmazhat. 
A rendszer figyelembe veszi a célzási pontosság növelése érdekében a következőket:

$\rightarrow$ a fegyverek hátra lökési erejét;

† a helikopter tömegközéppontját.

\section{Felépítése}

† egy központi számítógép a különböző számítási feladatok elvégzésére;

$\uparrow$ oldalanként $1-1 \mathrm{db}$ fegyver függesztési pont;

$\downarrow$ Wescam (MX15) nappal és éjjel is alkalmazható, elektro-optikai felderítő és célkövető kamerarendszer;

$\uparrow$ Thales (Scorpion) monokuláris sisak célzó és kijelző [38] (12. ábra).

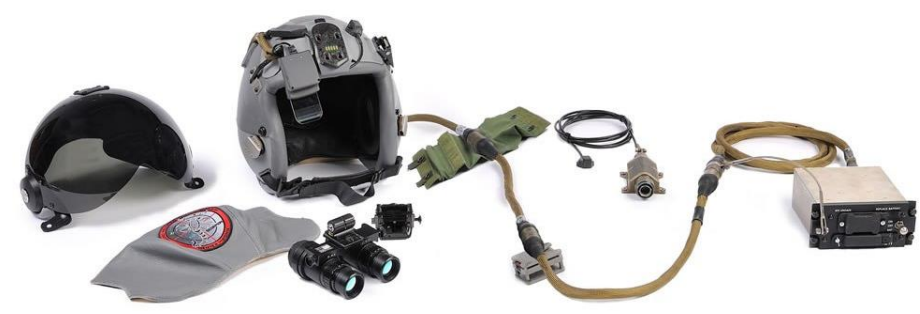

12.ábra Sisak célzó és kijelző [8]

\section{Fegyverzet}

A Hforce fegyverrendszer első éleslövészetét a H145M típusú helikoptereken 2017-ben Magyarországon hajtották végre. Ahol az FN Herstal HMP400 ${ }^{26}$ konténer, a Nexter NC621 20 mm-es gépágyú-konténer és a Thales FZ231 rakéta indító blokkok fedélzetre történő integrálásnak utolsó lépéseként, sikeres teszteléseket hajtottak végre [39].

Majd, ezt követően 2017. decemberében a Thales FZ275 70 mm-es félaktív lézer irányítású levegő-felszín (SAL) ${ }^{27}$ rakéták alkalmazására is sor került [40].

\section{Tüzfegyverek}

Az FN Herstal HMP400 konténert (13. ábra) a helikopterek és hangsebesség alatti merevszárnyú repülőgéphez fejlesztették ki és eddig az FN M3P 12,7 mm-es géppuska integrálását végezték el (6. ábra). A konténer vészhelyzet esetén ledobható a légijárműről. A géppuska elméleti tüzgyorsasága 950-1100 lövés/min, lőszerjavadalmazása 400 löszer, hatásos lőtávolsága 1850 m, élettartama 10000 lövés [41] [42].

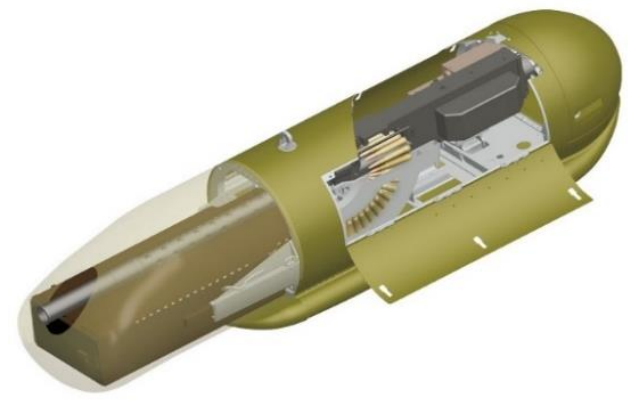

13. ábra FN Herstal HMP400 konténer [41]

\footnotetext{
${ }^{26}$ HMP - Heavy Machine Gun Pod

${ }^{27}$ SAL - Semi-Active Laser, félaktív lézer irányítású
} 
A Nexter NC621 20 mm-es gépágyú-konténer (14. ábra), amit szintén a helikopterek és hangsebesség alatti merevszárnyú repülőgépen történő alkalmazásra terveztek, a M621 20 mm-es gépágyút tartalmazza. A gépágyú elméleti átlagos tűzgyorsasága 750 lövés/min, hatásos lőtávolsága 2000 m, lőszerjavadalmazása 180 lőszer [43].

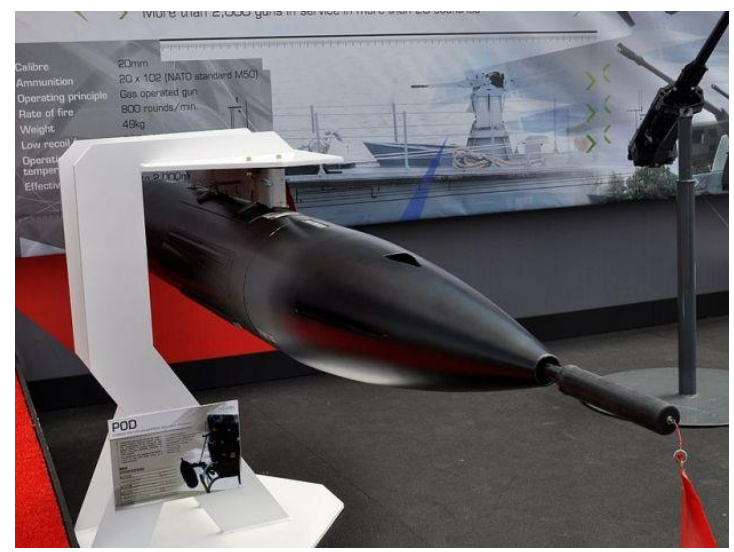

14. ábra Nexter NC621 gépágyú konténer [8]

\section{Nemirányítható rakéták}

A nemirányítható rakéták a nem vagy a gyengén páncélozott célok, közepesen megerősített beton objektumok támadására alkalmazhatóak. A Thales FZ231 rakéta indító blokk (15. ábra), $12 \mathrm{db} 70$ mm-es nemirányítható rakéta indítására képes. A rakéták harci részei igen különbözőek lehetnek és indítási távolságuk is változó, ami függ a hajtómü típusától és a harci rész tömegétől, a különböző változatok miatt ez 7100-9000 m közé esik.

† FZ71 HEGP - High Explosive General Purpose - a nagy hatóerőjü, álalános célú;

† FZ319 HEAP - High Explosive Armour Piercing - nagy hatóerőjü páncéltörő;

$\rightarrow$ FZ181 FS - Flash Signature - világító;

† FZ120 IP - Inert Practice, gyakorló súlymakett;

† FZ149 MULTIDART - 36 db egyenként 35 g-os nyíl megsemmisítő elemet tartalmaz;

$\neg$ FZ122 Flechette -2200 db egyenként 1,3 g-os nyíl megsemmisítő elemet tartalmaz [44] [45].

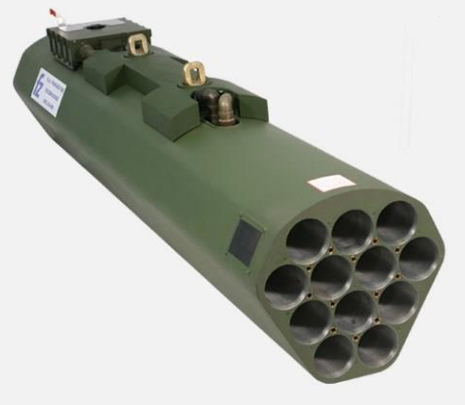

15. ábra FZ231 rakéta indító blokk [8]

\section{Irányítható rakéták}

Az FZ275 LGR - Laser Guided Rocket - félaktív lézer önirányítású rakéta (16. ábra) az indítása során egy lézer célmegjelölővel meg kell jelölni a célt, melyről a visszaverődő sugarakat egy nagyérzékenységű célkoordinátor érzékeli, majd kidolgozza az irányító jelet, mely a rakéta kormány-gépéire kerül [46]. 
A célmegjelölés történhet a rakéta indítása előtt (LOBL) ${ }^{28}$ vagy után $(\mathrm{LOAL})^{29}$ is, de akár egy másik platformról is, például egy katona egy célmegjelölővel, vagy egy másik légijármü is megteheti. Ez a sokoldalúság a helikopter számára sokkal nagyobb túlélőképességet és a támadásra való képességet biztosít anélkül, hogy az ellenséget meg kellene közelítenie. FZ275 félaktív lézer önirányítású rakéta ürmérete 70 mm, hatótávolsága 6000 m, szórása kisebb, mint 1 m [47].

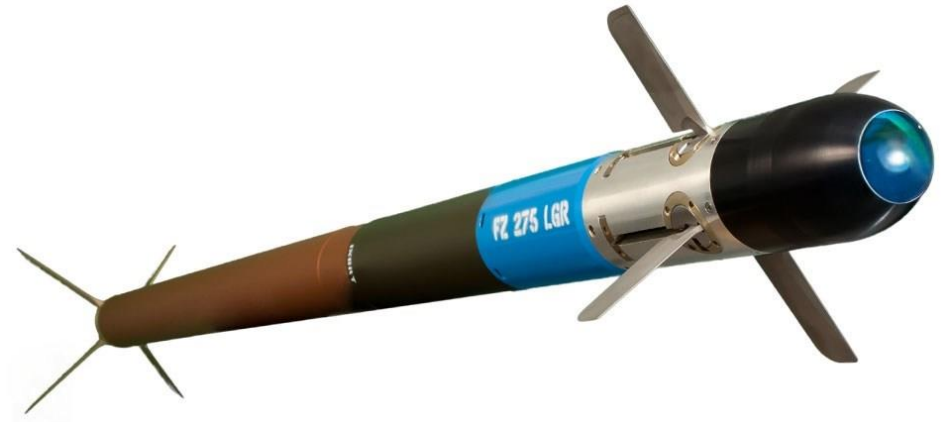

16. ábra FZ275 félaktív lézer önirányítású rakéta [8]

\section{KÖVETKEZTETÉSEK}

A cikkben a Magyar Honvédség beszerzés alatt álló Airbus H145M típusú helikopter fejlesztésének lépéseit, főbb harcászati-technikai jellemzőit és a fegyver rendszerét mutattam be, ezen kívül megvizsgáltam a helikopter fejlesztése során milyen túlélőképességet növelő elemeket alkalmaztak. A helikopterek hatékonysági mutatójának egyik legfontosabb elemét a túlélőképességet, számos tényező, többek között különféle műszaki, technikai megoldások képesek befolyásolni. Elemeztem és bemutattam a túlélőképességet növelő tényezők közül, milyen szerkezeti felépítésből adódó müszaki megoldások és milyen fedélzeti önvédelmi elektronikai eszközök kerültek felszerelésre a helikopterre.

Az Airbus H145M esetében a tervező és gyártó vállalat a túlélőképességet növelő müszaki megoldások széles spektrumát alkalmazta. A korszerü avionikai rendszerek, többek között, mint a zavarvédett, titkosított, műholdas kommunikációra alkalmas VHF/UHF rádióállomások, 4 csatornás robotpilóta, idegen-barát felismerő berendezés, illetve éjjellátó-kompatibilis fülke müszerezettség mind hozzájárulnak a túlélöképesség és a hatékonyság növeléséhez.

A szerkezeti megoldásokat vizsgálva a Magyar Honvédségben először fog megjelenni Fenestron típusú faroklégcsavarral felszerelt helikopter.

Azonban megállapítható, hogy a forgószárnyas képesség megújításának egyik legfontosabb eleme az, hogy az Airbus H145 rendelkezni fog olyan fedélzeti elektronikai önvédelmi rendszerekkel, mint a korszerü radar és lézerbesugárzás-jelzők, valamint a rakéta támadásra figyelmeztető rendszer, illetve a passzív radar- és infravörös önirányítású rakéták elleni csapdák, amelyek nagyfokú technológiai fejlettséget és hatékonyságot adnak a jelenleg rendszeresített helikopterekhez képes, biztosítva a forgószárnyas képesség megújítását a túlélőképesség növelés vonatkozásában.

\footnotetext{
${ }^{28}$ LOBL - Lock-on Before Launch, célmegjelölés a rakéta indítása előtt

${ }^{29}$ LOAL - Lock-on After Launch, célmegjelölés a rakéta indítása után
} 
További fejlesztésként az aktív radar (RFJ) ${ }^{30}$, lézer infravörös védelmi eszközök (IRCM) ${ }^{31}$ és nagy hatóerejü kumulatív vagy tandem kumulatív típusú harcirésszel rendelkező irányítható páncéltörő rakéták $\left(\mathrm{HEAT}^{32}\right.$ vagy HEAT $\mathrm{TCh}^{33}$ ) felszerelésével lehetne növelni a helikopter harci túlélőképességét és hatékonyságát.

A légijárművek túlélőképességét befolyásoló tényezők azonosítására, rendszerezésére vonatkozó kutatások napjainkban is zajlanak, minden haderő elemi érdeke ezen tényezők feltárása, hogy a rendszeresített és alkalmazott repülőeszközei harctéri hatékonyságát növelni tudja. Ez azért fontos, mert a helikopter alkalmazása a modern harctéren és béketámogató müveletek során rávilágíthat a típus előnyeire és hátrányaira, amit egyéb eljárásokkal, módszerekkel kell szükség szerint ellensúlyozni.

\section{FELHASZNÁLT IRODALOM}

[1] Honvédelem, „Folytatódik a haderő fejlesztése - új katonai helikoptereket szerez be a honvédség,” [Online]. Available:

https://honvedelem.hu/cikk/111144_folytatodik_a_hadero_fejlesztese_uj_katonai_helikoptereket_szerez_ be_a_honvedseg.

[2] Airportal, „Airbus Helicopters H145M katonai helikoptereket vásárol a magyar honvédség,” [Online]. Available: https://airportal.hu/airbus-helicopters-h145m-katonai-helikoptereket-vasarol-a-magyar-honvedseg/.

[3] Wikipedia The Free Encyclopedia, „MBB/Kawasaki BK 117,” [Online]. Available: https://en.wikipedia.org/wiki/MBB/Kawasaki_BK_117.

[4] Wikipedia The Free Encyclopedia, „Eurocopter EC145,” [Online]. Available: https://en.wikipedia.org/wiki/Eurocopter_EC145.

[5] Wikipedia The Free Encyclopedia, „Airbus Helicopters,” [Online]. Available: https://en.wikipedia.org/wiki/Airbus_Helicopters.

[6] EASA, „Airbus Helicopters EC145 (BK117),” [Online]. Available: https://www.easa.europa.eu/sites/default/files/dfu/EC145\%20(BK117)_FamilyDraft\%20Report_\%2029\%2004\%2014\%20-\%20draft.pdf.

[7] Airbus, „H145-Technical Date,” [Online]. Available: https://www.airbus.com/helicopters/civilhelicopters/light-twin/h145.html\#medialist_copy_copy_-document-document-all_ml_0-5.

[8] Thai Military and Asian Region, „H145M Battlefield Support Helicopter,” [Online]. Available: https://thaimilitaryandasianregion.wordpress.com/2016/03/05/h145m-battlefield-support-helicopter-france/.

[9] G. Kovács, „Forgószárny vibrációcsökkentés technikai megoldásai,” Repüléstudomány Közlemények 2013/3, pp. 1-7, 2013.

[10] Thales, „Are those aircraft friendly or not? How to identify your allies,” [Online]. Available: https://www.thalesgroup.com/en/worldwide/defence/news/are-those-aircraft-friendly-or-not-how-identifyyour-allies.

[11] Aero News Network, „Eurocopter Teams With French Authorities To Test New Medevac Route,” [Online]. Available: http://www.aero-news.net/index.cfm?do=main.textpost\&id=77ecebb5-7d4c-4f4fa9ac-b4120c974b81.

[12] Aerospace Online, „MEGHAS Avionics Certified on EC 135,” [Online]. Available: https://www.aerospaceonline.com/doc/meghas-avionics-certified-on-ec-135-0001.

[13] Thai Military and Asian Region, „H145M Battlefield Support Helicopter, France,” [Online]. Available: https://thaimilitaryandasianregion.wordpress.com/2016/03/05/h145m-battlefield-support-helicopter-france/.

[14] L. Szilvássy, A harci helikopterek fegyverrendszerének modernizációs lehetőségei a Magyar Honvédségben, Doktori (PhD) Értekezés, Budapest: ZMNE, 2008, pp. 96-104.

[15] L. Kavas, Harcászati repülőgép kiválasztásának módszere gazdasági - hatékonysági mutatók alapján, kis létszámú haderő légierejének korszerüsítésére, Doktori (PhD) értekezés,, Szolnok: ZMNE, 2009.

\footnotetext{
${ }^{30}$ RFJ - Radio Frequency Jamming, Rádió frekvenciás zavarás

${ }^{31}$ IRCM - Infrared Countermeasures, Infravörös zavarás

${ }^{32}$ HEAT - High explosive anti-tank, nagy hatóerejü kumulatív

${ }^{33}$ HEAT TCh -Tandem Charge tandem kumulatív
} 
[16] R. E. Dr. Ball, The Fundamentals of Aircraft Combat Survivability: Analysis and Design, USA: American Institute of Aeronautics and Astronautics, 2003, p. 895. DOI: https://doi.org/10.2514/4.862519

[17] Z. Rolkó, „Helikopterek túlélőképessége,” Repüléstudomány Közlemények 2013/1, pp. 1-14, 2013.

[18] G. Dr. Óváry, „Biztonság és repüléstechnikai megoldások katonai helikopterek harci túlélőképességének javítására," Repüléstudomány Közlemények 2005/2, pp. 1-14, 2005.

[19] Meggitt, „Fuel Systems for Aerospace,”[Online]. Available: https://www.meggitt.com/productsservices/fuel-systems-tanks/.

[20] Airbus, „H145M infographic,” [Online]. Available: https://www.airbus.com/helicopters/militarymissions/armed-scout.html\#medialist_copy_copy_1396037421-image-infographic-all_ml_0-3.

[21] Wikipedia The Free Encyclopedia, „Crashworthiness,” [Online]. Available: https://en.wikipedia.org/wiki/Crashworthiness.

[22] FAA William J. Hughes Technical Center, „Aircraft Crasworthiness Research Program,” [Online]. Available: http://www.tc.faa.gov/its/cmd/visitors/data/AAR-430/crashwor.pdf.

[23] Jetplanes, „Légierőnk új típusa, a H145M,”[Online]. Available: https://jetplanes.blog.hu/2018/08/14/legieronk_uj_tipusa_a_h145m.

[24] Globalsecurity, „H145M,” [Online]. Available: https://www.globalsecurity.org/military/world/europe/ec645.htm.

[25] M. Légimentők, „Helikoptereink, Eurocopter EC135 T2 CPDS,” [Online]. Available: http://portal.legimentok.hu/technika/helikoptereink.

[26] Wikimedia, ,Fenestron,” [Online]. Available: https://commons.wikimedia.org/wiki/File:Fenestron_555c.jpg.

[27] Wayback Machine, „Eurocopter EC145, Technology \& Design,” [Online]. Available: https://web.archive.org/web/20130425043926/http://www.eurocopter.com/site/en/ref/Technology_94.html.

[28] J. Bozóki, „Katonai repülőeszközök aktív és passzív védelmi lehetőségei infravörös önirányítású rakéta találat ellen,” Repüléstudomány Közlemények 2012/1, pp. 1-8, 2012.

[29] Wikipedia The Free Encyclopedia, „Radar warning receiver,” [Online]. Available: https://en.wikipedia.org/wiki/Radar_warning_receiver.

[30] Hensoldt, „ALTAS-2Q Advanced Laser Threat Alerting System,” [Online]. Available: https://www.hensoldt.net/solutions/air/electronic-warfare/altas-2q/.

[31] Wikipedia The Free Encyclopedia, „Beam riding,” [Online]. Available: https://en.wikipedia.org/wiki/Beam_riding.

[32] A.-J. Mubarak, PhD THESIS, The vulnerability of laser warning systems against guided weapons based on low power lasers, USA: Cranfield University, 2006.

[33] Hensoldt, „MILDS AN/AAR-60 Missile Warning System,” [Online]. Available: https://www.hensoldt.net/fileadmin/hensoldt/Datenb1\%C3\%A4tter/0631_17_MILDS_AN_AAR60_datasheet_E_intranet.pdf.

[34] Wikipedia The Free Encyclopedia, ,Missile approach warning system,” [Online]. Available: https://en.wikipedia.org/wiki/Missile_approach_warning_system.

[35] Thai military and asian region, „EADS AN / AAR-60 missile launch detector,” [Online]. Available: https://thaimilitaryandasianregion.wordpress.com/2015/11/14/.

[36] S. Dr. Vass, „Katonai repülőeszközök túlélési lehetőségei az infravörös sugárzású rakéták támadásai ellen," Hadmérnök, pp. 1-13, 2006.

[37] MBDA systems, ,Saphir-M decoying for protection,” [Online]. Available: https://www.mbdasystems.com/?media-center=saphir-m-5.

[38] Wikipedia, „Chaff (countermeasure),” [Online]. Available: https://en.wikipedia.org/wiki/Chaff_(countermeasure).

[39] Airbus, „Airbus Helicopters completes first firing campaign with HForce-equipped H145M,” [Online]. Available: https://www.airbus.com/newsroom/press-releases/en/2017/11/airbus-helicopters-completesfirst-firing-campaign-with-hforce-e.html.

[40] Airbus, „Ready to serve: Airbus Helicopters' militarized H145M receives its on-time EASA certification,” [Online]. Available: https://www.airbus.com/newsroom/press-releases/en/2015/05/ready-to-serve-airbushelicopters-militarized-h145m-receives-its-on-time-easa-certification.html.

[41] Airbus, „H145M successfully launched $70 \mathrm{~mm}$ Laser Guided Rockets during its firing campaign in Sweden," [Online]. Available: https:/www.airbus.com/newsroom/press-releases/en/2018/01/h145msuccessfully-launched-70mm-laser-guided-rockets-during-its.html.

[42] FNAmerica, „FN® HMP400 Pod,” [Online]. Available: https://fnamerica.com/products/fn-airborne-podsystems/fn-hmp400-pod/. 
[43] FNAmerica, „FN® M3P,” [Online]. Available: https://fnamerica.com/products/weapon-systems/fn$\mathrm{m} 3 \mathrm{p} /$ ?referrer=military.

[44] Nexter, „NC 621 Cannon pod for helicopters and light aircrafts,” [Online]. Available: http://preprod.nextergroup.fr/en/products/item/406-nc-621-cannon-pod-for-helicopters-and-light-aircrafts.

[45] Thales Belgium SA, „Warhead,”[Online]. Available: http://fz.be/products.php?p=11.

[46] Thales Belgium SA, „World leader in the field of 70mm (2.75") air-to-ground rocket systems,” [Online]. Available: http://fz.be/FZ231.

[47] I. Papp, „Repülőfedélzeti irányítható rakéták,” Repüléstudományi Közlemények 2017/2, pp. 1-14, 2017.

[48] Thales Belgium SA, „Laser Guided Rocket,” [Online]. Available: http://fz.be/laser-guided-rocket\#6.

[49] Wikipedia The Free Encyclopedia, ,Radar jamming and deception,” [Online]. Available:

https://en.wikipedia.org/wiki/Radar_jamming_and_deception.

\section{THE H145M HELICOPTER COMBAT SURVIVABILITY}

In this article I would like to introduce the Airbus H145M multi-role battlefield support helicopter. After describing the development, design and the main technical characteristics, I will analyse the helicopter in terms of the combat survivability, detailing the structure, the various of the self-defence systems, and finally the weaponry currently used.

Keywords: combat survivability, helicopter, self-defence system, weaponry

\begin{tabular}{ll}
\hline Domán László őrnagy, & Major László Domán \\
főtechnológus (osztályvezető helyettes) & chief technologist (Deputy Head of Dep.) \\
Magyar Honvédség Légijármü Javítóüzem & Hungarian Defence Forces Aircraft Repair Plant \\
Müszaki Fejlesztési és Technológiai Osztály & Technical Development and Technological Department \\
doman.laszlo79@gmail.com & doman.laszlo79@ gmail.com \\
orcid.org/0000-0002-4472-2609 & orcid.org/0000-0002-4472-2609 \\
\hline
\end{tabular}

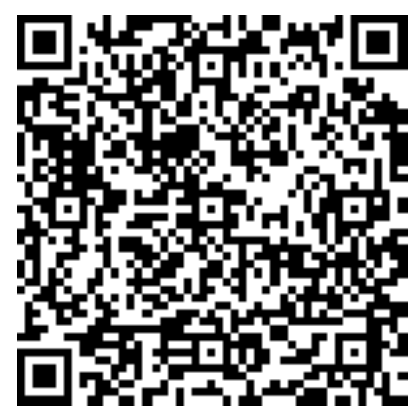

http://journals.uni-nke.hu/index.php/reptudkoz/article/view/308/37 